Studia Judaica 20 (2017), nr 1 (39), s. 17-45

doi:10.4467/24500100STJ.17.002.7728

Piotr Laskowski

\title{
Revolution in a Shtetl: Literary Image and Historical Representation*
}

\author{
I realize that if through science I can seize phenomena and enumerate them, \\ I cannot, for all that, apprehend the world. \\ Albert Camus
}

\begin{abstract}
The paper analyses a specific form of revolutionary collectivity referred to as akhdes by Jewish militants of 1905 . This peculiar political subjectivity, which emerged independently of mass political parties, could hardly be recognized and apprehended by historians. However, it was perceived by some Yiddish writers who instantaneously fictionalized revolutionary events of 1905 . The way the revolted crowd (oylem) was rendered both in historical and literary works is reconsidered with reference to the concepts coined by recent political philosophy (particularly, Gilles Deleuze, Félix Guattari, and Paolo Virno). The paper is composed of three parts. The first part reviews briefly some of the attempts at writing the history of crowds. The second part is devoted to revolutionary events of 1905 in a specific place, the shtetl of Krynki, which—due to the intensity of the revolt there-attracted particular attention of historians. The third part focuses on Isaac Meir Weissenberg's novella, $A$ Shtetl, published in 1907, to suggest a political reading that could inform historical narrations insofar as they try to apprehend the dynamics of the revolution itself.
\end{abstract}

Keywords: Revolution of 1905, Jewish socialism, Weissenberg, shtetl, Krynki.

* I owe a debt of gratitude to Professors Marcin Wodziński, Monika AdamczykGarbowska, and Scott Ury for their meticulous editorial work. Their stern yet unfailingly constructive feedback saved me from a rash of mistakes. Likewise, their extensive and insightful comments have significantly enhanced this article. Of course, I am solely responsible for those errors that remain. 
The Revolution of 1905 is generally regarded as a turning point in the construction of modern political identities, for this milestone event triggered a large-scale political mobilization and the coalescence of new forms of political subjectivity. Instrumental to this process, scholars contend, were mass political parties that had only been founded a few years earlier. At the very moment the insurgency erupted, though, another form of political subjectivity emerged, one that was independent of party enterprise. Young Jewish revolutionaries of 1905 referred to it as akhdes - unity and association. Throughout this paper, I will argue that this term corresponds to the concept of "multitude" as defined by the Italian philosopher Paolo Virno: "a plurality which persists as such in the public scene, in collective action, in the handling of communal affairs, without converging into a One ... the form of social and political existence for the many, seen as being many." ${ }^{1}$ On the face of things, the meaning of akhdes is at odds with the very concept of multitude. However, as Virno notes, "the multitude does not rid itself of the One, of the universal, of the common/shared; rather, it redefines the One."”

Jonathan Frankel has duly observed that "Akhdes (Hebrew: akhdut) like organizatsiye (the Organization) - was a term often applied to the Bund." 3 In reconstructing the dynamics of the 1905 Revolution, then, the following questions beg asking: How did akhdes turn into organizatsiye? And how was this idea of unity appropriated by the political parties? A striking feature of the Revolution, as well as the struggles that preceded it, was the tension between the parties and the insurgent crowds. ${ }^{4}$ Aspiring to lead (and represent) these masses from a political and historic standpoint, the parties considered them a homogeneous whole. The Revolution of 1905 was a medley of collective actions that spread like wildfire throughout the Russian Empire-among Jews and

${ }^{1}$ Paolo Virno, A Grammar of the Multitude: For an Analysis of Contemporary Forms of Life, trans. Isabella Bertoletti, James Cascaito, Andrea Casson (Los Angeles, 2004), 21.

2 Ibid., 42.

${ }_{3}^{3}$ Jonathan Frankel, Crisis, Revolution, and Russian Jews (New York, 2009), 82, n. 23. For a more comprehensive analysis of the relation between akhdes and the Bund, see François Guesnet, "Khevres and Akhdes: The Change in Jewish Self-Organization in the Kingdom of Poland before 1900 and the Bund," in Jack Jacobs (ed.), Jewish Politics in Eastern Europe: The Bund at 100 (Basingstoke, 2001), 3-13.

${ }^{4}$ Cf. Elżbieta Kaczyńska, "Partie polityczne a masowy ruch robotniczy w Królestwie Polskim na przełomie XIX i XX wieku. Badania historyczne - ich krytyka i propozycje [Political Parties and Mass Workers' Movement in the Kingdom of Poland at the Turn of the 19th and 20th Centuries: Historical Research - Critique and Suggestions]," Przeglad Historyczny 81 (1990), 1-2: 125-138. 
non-Jews, in cities, towns, and villages. At one and the same time, though, it remained a local and internally differentiated phenomenon; the revolt was a struggle for autonomy, self-organization, and "political existence for the many." During the early stages of the insurrection, the political parties could hardly control, much less master, the revolutionary process, as they strained to keep up with the torrent of events. ${ }^{5}$ This same perspective will also undergird my deliberations on revolutionary violence.

To fathom revolutionary multitude, one must search for narrative forms that are adept at recognizing this sort of phenomena. Linear historiographical narrations that concentrate on fixed political subjectivities and progress via causal explanations aimed at unveiling mechanisms or structures do not fit the bill. What is needed is a history capable of instantaneously apprehending ${ }^{6}$ revolts as they physically manifest themselves in the form of mass strikes and demonstrations. ${ }^{7}$ The fields of microhistory and oral history have made headway on this front. In commenting on his Biografia di una città ${ }^{8}$ the pioneering oral historian Alessandro Portelli has declared that

[T] he minute fragmentation and recomposition of the voices (and their interaction with other sources) is recreated to convey the dialogic experience of a town's story told through many voices, less as objective reproduction than as creative representation. The models are derived less from history and sociology than from literature. ${ }^{9}$

Following in Portelli's footsteps, I will demonstrate how literature, rather than historical writing, managed to grasp the micropolitics of the 1905 Revolution.

${ }^{5}$ Rosa Luxemburg perspicaciously observed this shortcoming; see Rosa Luxemburg, "The Mass Strike, the Political Party, and the Trade Unions," in Helen Scott (ed.), The Essential Rosa Luxemburg: "Reform or Revolution" and "The Mass Strike" (Chicago, 2008), 140-141, 161, passim.

${ }^{6}$ For a reinterpretation of the Kantian term "instantaneous apprehension," see Gilles Deleuze, Félix Guattari, $A$ Thousand Plateaus, trans. Brian Massumi (Minneapolis-London, 1987), 27, passim.

${ }^{7}$ Drawing on Charles Péguy's Clio: Dialogue de l'histoire et de l'âme païenne (Paris, 1931), Deleuze and Guattari identify "two ways of considering the event.... One consists in going over the course of event, in recording its effectuation in history, its conditioning and deterioration in history. But the other consists in reassembling the event, installing oneself in it as in becoming ... going through all its components or singularities." Gilles Deleuze, Félix Guattari, What Is Philosophy?, trans. Hugh Tomlinson, Graham Burchell (New York, 1992), 111.

8 Alessandro Portelli, Biografia di una città. Storia e racconto: Terni, 1830-1985 (Torino, 1985).

9 Alessandro Portelli, "Oral History in Italy," in David K. Dunaway, Willa K. Baum (eds.), Oral History: An Interdisciplinary Anthology (Walnut Creek, 1996), 404. Emphasis mine. 
This paper also leans on the French philosophers Gilles Deleuze and Félix Guattari, whose research was strongly influenced by their personal experiences during another revolution: May 1968. In the first place, I have adopted the distinction that they made between "molar"10 and "molecular." The ensuing discussion is indeed predicated on their observation that "every politics is simultaneously a macropolitics and a micropolitics." On the macropolitical level, there are political parties with a molar outlook on social class or nation. Conversely, there are molecular crowds "that do not have the same kind of movement, distribution, or objectives and do not wage the same kind of struggle." ${ }^{11}$ Even if the parties more or less hold sway over the crowd, the latter preserves its molecular dynamics:

There is always something that flows or flees . . . : things that are attributed to a "change in values," the youth, women, the mad, etc. May 1968 in France was molecular, making what led up to it all the more imperceptible from the viewpoint of macropolitics ... [T] hose who evaluated things in macropolitical terms understood nothing of the event because something unaccountable was escaping. ${ }^{12}$

Against this backdrop, I will try and detect those elusive, inscrutable elements of 1905 that have fallen under the radar of macropolitical analysis.

The present article consists of three parts. To begin with, I will delve into the notion of a crowd and survey a handful of the attempts at chronicling this phenomenon. As discussed below, historiographers tend to "represent" the crowd as a unitary collective body, be it a unity of destructive passions or a unity of "traditional" forms of life and struggle. Interestingly enough, as it pertains to the events of 1905 , historians have generally deemed the crowd a pre-modern social formation that, owing to the onset of the industrial age, had to be transformed into a working class-a proletariat. This metamorphosis turned out to be a frantic process. At the moment of revolt, the crowd reemerged as a disturbing residue, a chaotic force, which political organizations toiled to subsume.

${ }^{10}$ Deleuze and Guattari contrast the "molar" with the "molecular" in both volumes (i.e., Anti-Oedipus and Thousand Plateaus) of their work Capitalism and Schizophrenia. In their estimation, the "molar" constitutes "macroscopic social formations" that are amenable to representation. Consequently, the "entire molar organization has the function of binding the molecular process." Gilles Deleuze, Félix Guattari, Anti-Oedipus, trans. Robert Hurley, Mark Seem, Helen R. Lane (Minneapolis, 1983), 183, 320. What is more, they posit that molar entities are "subjects, objects, or form that we know from the outside and recognize from experience, through science, or by habit," Deleuze, Guattari, $A$ Thousand Plateaus, 275.

11 Ibid., 213.

12 Ibid., 216. 
In the second part of this article, we will turn our attention to a specific case study: the strike of January 1905 in Krynki-a Polish shtetl in the Grodno province. The sheer intensity of this demonstration gave rise to the proclamation of a short-lived autonomous republic. ${ }^{13}$ Despite the extraordinary nature of this particular strike, Krynki appears to be emblematic of the revolutionary shtetls in 1905. For this reason, I will critically reevaluate the way this episode has been depicted in historical narrations. The discussion centers around the relations between the crowd and the political parties that were active in Krynki: the Bund and the Social Democracy of the Kingdom of Poland and Lithuania (SDKPiL). In this context, I will also point out those writers who were conscious of the micropolitical-cum-molecular dynamics of the revolutionary crowd.

The third section of this paper takes stock of Isaac Meir Weissenberg's A Shtetl. Published in 1907, this novella exemplifies the "instant fictionalization" of the Russian Revolution. ${ }^{14}$ Cognizant of the fact that the source material consists primarily of media reports, leaflets, and brochures circulated by political parties, along with their activists' memoirs, Jonathan Frankel has duly stressed the historical value of literary works: "There is such a relative paucity of diaries and personal correspondence surviving from 1905. Belles lettres thus fills an important gap." 15 My prime objective, though, is not to submit Weissenberg's novella for historical scrutiny, but rather to illustrate its value as an "instantaneous apprehension" of revolutionary multitude. Put differently, I will suggest a political reading that draws heavily on the Deleuzeguattarian concept of "minor literature." In works that fall under this heading, the language repudiates fixed and stable universalities. Additionally, minor literature is inherently political. "Everything," Deleuze and Guattari contend, "takes on a collective value ... literature finds itself positively charged with the role and function of collective, and even revolutionary, enunciation." 16 The two scholars deemed this genre an unadulterated report on "politics that is neither imaginary nor symbolic" - a report that "rests only on tests of experience." 17 As such, I will read $A$ Shtetl as a dispatch on the revolutionary experience of 1905.

13 This episode netted a great deal of press coverage not only in Russian Poland, but in socialist, anarchist, and radical journals across Europe. For instance, Le Radical 34 (3 Feb. 1905), 1; and two years later, Les Temps Nouveaux 20 (14 Sept. 1907), 8.

${ }^{14}$ Frankel, Crisis, Revolution, and Russian Jews, $72 \mathrm{ff}$.

15 Ibid., 74.

${ }^{16}$ Gilles Deleuze, Félix Guattari, Kafka: Toward a Minor Literature, trans. Dana Polan (Minneapolis-London, 1986), 17.

17 Ibid., 7. 
Dubious as this strategy may be, I will juxtapose this novella with the historical accounts of the strike in Krynki. It is widely assumed that the story is set in Weissenberg's hometown of Żelechów. In my estimation, the author considered this work an account of whichever shtetl amid the Revolution. Not only did he eschew identifying the town by name, but as Frankel cautiously writes, "[I]t is not apparent how far $A$ shtetl . . . was based on personal observation" of the events in Żelechów. ${ }^{18}$ Weissenberg availed himself of material that can be traced to many of the insurgent shtetls: secret meetings in outlying forests; the mobilization of songs as a form of resistance; rivalries between political parties; their activists' efforts to master the crowd; revolutionary marches that culminated with the severing of telegraph wires; and last but not least, the occupation of the synagogue by the revolutionary crowd. In the introduction to her English translation of Weissenberg's novella, Ruth Wisse observes that "the process of radicalization as it is chronicled in A Shtetl was repeated in hundreds of similar towns in that year when political and economic strikes together are said to have involved some three million men ... The shtetl is both place of action and confining point of view." ${ }^{19}$ In fact, it was this perspective that enabled Weissenberg to recognize "the independent force of the crowd." 20

If elements of his narration can also be found in documents from many other towns, cities, and even metropolises like Warsaw, why do I insist that A Shtetl specifically describes the events that transpired in Krynki? Given its extraordinary vigor and scale, the uprising in this town indeed became a focal point of historians' accounts of the 1905 Revolution. Though only discernible via cracks and inconsistencies in their narration, these works unearthed the dynamics of the revolutionary multitude, which Weissenberg fully apprehended in a straightforward manner.

As Wisse notes, "almost alone among Yiddish writers, Weissenberg was a worker and the son of workers, and he was determined to bring a genuine working-class voice into the literature." ${ }^{21}$ This background most likely explains why $A$ Shtetl constitutes a unique example of "minor literature." In fact, it sharply diverges from the molar narrations on 1905 that were published at around the same time, not least S. An-sky's Bund-oriented

${ }^{18}$ Frankel, Crisis, Revolution, and Russian Jews, 95.

${ }^{19}$ Ruth R. Wisse, "Introduction," in A Shtetl and Other Yiddish Novellas, ed. and trans. Ruth R. Wisse (Detroit, 1986), 26.

${ }^{20}$ Ibid., 27.

${ }^{21}$ Ibid. 
In shtrom [With the Flow]. In my estimation, Weissenberg produced the most informative reconstruction of the 1905 Revolution as it played out in the shtetls of Russian Poland. All the more so, this novella offers a precise and insightful analysis of revolutionary and counter-revolutionary violence.

\section{The Crowd in History}

The use of the term "crowd" in the social sciences and, thus, historiography has varied over the years. For this reason, I would like to open this discussion by outlining briefly the evolution of its meaning. Despite significant advances in the pertinent scholarship, the term "crowd" remains vague and imprecise. In 1964, George Rudé, a pioneer in this field, observed that "Perhaps no historical phenomenon has been so thoroughly neglected by historians as the crowd." 22 Twenty years later, Mark Harrison still felt compelled to open his summary of the research with the following remark: "An air of mystery surrounds the crowd." ${ }^{23}$ One of the reasons for this lacuna, he opines, is certainly the fact that "the anonymity of crowds is almost total. Documentary evidence regarding the attitudes and beliefs of crowd participants is difficult to locate: crowd members rarely leave records." 24

Following in the footsteps of Gustave Le Bon's trailblazing, fin-de-siècle study on this topic, sociologists and historians embraced his contention that the crowd is "little adapted to reasoning," 25 impulsive, irritable, credulous, intolerant, and dictatorial. Le Bon defined the crowd as "a gathering of individuals of whatever nationality, profession, or sex, and whatever be the chances that have brought them together." Far from thinking of the crowd as a multitude, he posited that "it forms a single being, and is subjected to the law of the mental unity of crowds." 26 This "mental unity," according to Le Bon, rendered the crowd a powerful force, but one that can only be leveraged for destructive purposes. ${ }^{27}$ From the late 1950 s, a number of

${ }^{22}$ George Rudé, The Crowd in History: A Study of Popular Disturbances in France and England, 1730-1848 (London, 1981 [1964]), 3.

${ }^{23}$ Mark Harrison, Crowds and History: Mass Phenomena in English Towns, 1790-1835 (Cambridge, 1988), 3. Influential as Harrison's ideas are, they have not been adopted in the present article.

${ }^{24}$ Ibid., 35.

${ }^{25}$ Gustave Le Bon, The Crowd: A Study of the Popular Mind (New York, 1896), xvii; originally published as Psychologie des foules (Paris, 1895).

${ }^{26}$ Ibid., 1-2; emphasis in the original.

${ }^{27}$ Ibid., xix. 
researchers finally began to challenge the prevailing image of the crowd as a chaotic, visceral, and innately violent entity.

Groundbreaking studies by Rudé and Edward P. Thompson ${ }^{28}$ have sought to defend the crowd against Le Bon and his disciples' "spasmodic view of popular history." ${ }^{29}$ Rudé urges scholars to contextualize the outbursts of "popular disturbances" and, above all, to determine "the aims, motives, and ideas underlying these activities." ${ }^{30}$ Building on these ideas, Thompson points to the "legitimizing notion" that characterizes the "moral economy" of the crowd. He argues as follows:

the men and women in the crowd were informed by the belief that they were defending traditional rights or customs; and, in general, that they were supported by the wider consensus of the community ... as to what were legitimate and what were illegitimate practices in marketing, milling, baking etc. ${ }^{31}$

This new approach has engendered a sort of de-radicalization of popular riots. The crowd had to become more responsible, disciplined, serious-minded, and concerned with rectifying the social order, rather than challenging it. Thompson's conception of "moral economy" has undoubtedly helped scholars debunk the short-sited notion that food riots were merely a "direct spasmodic, irrational response to hunger" 32 or "rebellions of the belly." ${ }^{33}$ From this point onward, the literature has underscored the existence of an autonomous crowd culture with its own values and inherited patterns of action, such as underground oaths and union organization. ${ }^{34}$ Accordingly, Thompson presented riots as an attempt to restore

${ }^{28}$ Edward P. Thompson, "The Moral Economy of the English Crowd in the Eighteenth Century," Past and Present 50 (1971), 76-136 (Thompson began working on this text in 1963).

${ }^{29}$ Ibid., 76.

${ }^{30}$ Rudé, The Crowd in History, 11. There is a close correspondence between Rudé's approach and Charles Tilly's idea of "popular contention." Diverging from Rudé, the latter underestimated the need for historical contextualization and sought to build a mathematical model of society featuring clearly defined, rival units—both individuals and groups alikethat assert their positions and negotiate their mutual relations. Tilly's analysis of reciprocal claims is patently molar. This, then, explains his endorsement of modern forms of organization (e.g., parliamentary representation and trade unions) that allow for a higher degree of coordination, thereby leaving a possibility, precarious as it may be, for social equilibrium. Nevertheless, Tilly uses his concept of "popular contention" to analyze "claim-making in which people gather, act together, and then disperse - that is, discontinuous claim-making." Charles Tilly, Popular Contention in Great Britain, 1758-1834 (Boulder-London, 2005), 16.

31 Thompson, "The Moral Economy," 78-79.

32 Ibid., 136.

${ }^{33}$ Ibid., 77.

${ }^{34}$ Ibid., 119, 128. 
order and justice. That said, he leaves no room for revolutionary rupture. Thompson feels compelled to edify the norms that he had identified. Consequently, he is unwilling to consider revolution as a time when the crowd dynamically appropriates and reinterprets both old traditions and new ideas. Emmanuel Le Roy Ladurie has drawn a rich, comprehensive, and compelling picture of an insurgent town on the basis of an in-depth study of the cultural backgrounds that seeded the crowd's rebellious selfexpression. Nevertheless, he concludes his study on a melancholy note: "Some things never change." 35

It bears noting that Thompson views the crowd as an inherently pre-industrial phenomenon. Tracking the evolution or "making" of the working class, he argues that crowds were superseded by the industrial proletariat and that the traditional "moral economy" was replaced by class consciousness. However, as Deleuze and Guattari observe, "classes are indeed fashioned from masses; they crystallize them. And masses are constantly flowing or leaking from classes." ${ }^{36}$ Thompson's affirmation of a proletarian discipline embodied in the modern, molar forms of political representation, not least trade unions and political parties, reflects the long-standing Marxist distrust of industrial-era crowds-what Marx dubbed the lumpenproletariat or "the whole indefinite, disintegrated mass, thrown hither and thither." 37 After being unified and restrained by the "moral economy," the premodern crowd is transformed into a working class, only to re-enter the historical stage as "rabble" and "social scum." In sum, historiography has come full circle as Thompson has conjured up a specter of Le Bon's violent crowd. This, then, has justified his call for molarly organizing the working class, which is up to the task of curbing revolutionary violence. ${ }^{38}$

35 Emmanuel Le Roy Ladurie, Carnival in Romans, trans. Mary Feeney (New York, 1980), 324.

${ }^{36}$ Deleuze, Guattari, $A$ Thousand Plateaus, 213.

${ }^{37}$ Karl Marx, "The Eighteenth Brumaire of Louis Bonaparte," in Karl Marx, Friedrich Engels, Collected Works (London-Moscow, 1975-2004), 11: 149. Elsewhere, Marx and Engels refer to this entity as "the social scum [lumpenproletariat], that passively rotting mass thrown off by the lowest layers of the old society." Karl Marx, Friedrich Engels, "Manifesto of the Communist Party," in eid., Collected Works, 6: 494.

38 This idea can be traced back to the Jacobins who preferred the revolutionary government over spasms of popular violence. Georges Jacques Danton articulated this thought in his famous appeal: "Soyons terribles pour dispenser le peuple de l'être [Let us be terrible so as to spare the people the need to be so];" Georges Jacques Danton, "Sur l'organisation du tribunal révolutionnaire et du pouvoir exécutif," in Auguste Vermorel (ed.), Oeuvres de Danton (Paris, 1867), 154. 
Compared to this linear narration, Eric Hobsbawm offers a more complex analysis. While sharing Thompson's affirmative view of the modern political approach to organizing the working class, Hobsbawm explains why "archaic forms of social movement" endure on the periphery: "The men and women with whom this book is concerned differ from Englishmen in that they have not been born into the world of capitalism ... with four generations of trade unionism." ${ }^{39}$ He portrays modernity as a violent, destructive, unstoppable force that cannot be molded by the people it engulfs:

[I]t comes to them from outside, insidiously by the operation of economic forces which they do not understand and over which they have no control ... They do not as yet grow with or into modern society: they are broken into it. . . Their problem is how to adapt themselves to its life and struggles, and the subject of this book is the process of adaptation (or failure to adapt) as expressed in their archaic social movements. ${ }^{40}$

Hobsbawm evidently believes that these "archaic" forms of struggle lack revolutionary potential. At best, they are a means of adaptation. Only modern political organizations, he argues, are capable of revolutionizing and transforming society.

A similar view of modernity is to be found in Scott Ury's pioneering work on the Revolution of 1905. In Ury's estimation, modernity "was not something that Jews defined, created, and controlled but, rather, something that they encountered, struggled with, and, in the end, attempted to master." ${ }^{41}$ His case study - the city of Warsaw—is a "chaotic, practically incomprehensible environment," 42 a place of "alienation, anonymity, and loneliness" 43 that is plagued by "almost epidemic violence." ${ }^{44}$ Therefore, the political ideologies and organized mass parties "should be seen as attempts to wield intellectual and social order over a particularly chaotic world." More specifically, "modern Jewish politics should be viewed as a discourse of order ... intended to codify, comprehend, and control such fundamentally elusive social and political components as community

${ }^{39}$ Eric J. Hobsbawm, Primitive Rebels: Studies in Archaic Forms of Social Movement in the 19th and 20th Centuries (Manchester, 1959), 3.

${ }^{40}$ Ibid.

${ }^{41}$ Scott Ury, Barricades and Banners: The Revolution of 1905 and the Transformation of Warsaw Jewry (Stanford, 2012), 8.

42 Ibid., 4.

${ }^{43}$ Ibid., 55.

${ }^{44}$ Ibid., 46. 
and self in times of rapid social change, political upheaval, and pervasive uncertainty." 45 Interested in the attempts to redefine the collective and political subjectivity, Ury criticizes the literature's "overconcentration on parties, ideologies, and leaders." That said, he only manages to orient his own research towards "structures, practices, and discourses that helped create modern Jewish politics." ${ }^{46}$ Ury's chief concern regards the "efforts by different leaders and organizations to redefine and transform the modern world from an unbound, undefined, and threatening myriad of practically incomprehensible phenomena to a bound, defined, and controlled intellectual, cultural, and political construct." ${ }^{47}$

At this juncture, I will place the spotlight on those same "incomprehensible phenomena" in an effort to go beyond their classification intothat is, appropriation, organization, and subjugation by-the discursive frameworks that Ury has expounded on. My objective is to recognize that problem, which perhaps eluded other scholars: the autonomous revolutionary multitude that managed to redefine itself in an independent fashion. As we will see, this multitude was a community devoid of precise boundaries and established centers of power, which only take form when such a collective is defined and subsumed by political frameworks. The focus of this paper is on the shared experience of becoming, the creative instance of revolt. Far from being chaotic, this moment spawns dynamic forms of assembly: strikes and demonstrations. To enhance our understanding of this inception, we must transcend the dichotomy between modern politics and archaic forms of social movement. With respect to the events of 1905 on the periphery, these interpretative paradigms are overly reductive. Revolutionary activity triggers the memory of the past and integrates the latter with modern political ideologies. To comprehend this intersection of memory, modernity, and the establishment of new forms of communal life, it is incumbent upon us to unearth the molecular crowd that was obscured by molar political organizations. The crowd was unencumbered by tradition, but did not constitute a "rabble."

Hints of the revolutionary crowds' independent activity turn up in historical accounts. In his seminal disquisition on the origins of the Jewish workers' movement in the Pale of Settlement, Ezra Mendelsohn occasionally points to a gap between the leaders of organized revolutionary parties

\footnotetext{
45 Ibid., 3-4.

${ }^{46}$ Ibid., 12.

47 Ibid., 17.
} 
or circles and insurgent Jewish masses. Between 1895 and 1904, over two thousand protests "spread from the shops to the factories, and from the large centres to the smaller towns." 48 In general, "the labor movement in the small communities was sparked by the arrival of workers from nearby cities, who were experienced in the techniques of agitation ... Despite this assistance from 'outside agitators,' it was the local workers themselves who led the movement in the provincial towns." ${ }^{49}$ A case in point is the strike held by Białystok weavers in 1895. According to Mendelsohn, this episode was a "spontaneous protest by the masses" that had not been authorized by socialist groups in the city. ${ }^{50}$ What is more, "subsequent attempts by the workers to take matters into their own hands met with a rebuke from socialists." ${ }^{51}$ In 1900, Bund leaders in Vilna went so far as to condemn strikes. From their vantage point, protests "had become so commonplace, they often attracted people who had no experience at organized protest" and thus "failed to appreciate the need for discipline and planning." 52 Additionally, he claims that "the tactics employed by the strikers often contradicted the ideological premises of the socialists." ${ }^{\prime 3}$

To Mendelsohn, then, it is quite clear that the energy of revolt was not so much instilled in the masses as it was an innate quality of crowds, who sought "to take matters into their own hands." Be that as it may, he refrains from determining what this independence actually entailed. Our attempt to fill this void builds on Arlette Farge and Jacques Revel's insights on the Paris riots of 1750 :

We understand the revolt itself as a persistent, a piecemeal, search for meaning which is not given at the beginning, and which only gradually reveals its true significance ... The events unrolled like a play that takes its framework from tradition but is improvised and scripted by the actors. The development was not a random affair however; the rioters themselves chose their locations and forms of expression and in exercising this choice they were constantly in the process of creating the significance of their own protest. ${ }^{54}$

${ }^{48}$ Ezra Mendelsohn, Class Struggle in the Pale: The Formative Years of the Jewish Workers' Movement in Tsarist Russia (Cambridge, 1970), 83. The above-cited estimate of the number of strikes comports with Ber Borokhov's; ibid., 85.

${ }^{49}$ Ibid., 83-84.

${ }^{50}$ Ibid., 92.

${ }^{51}$ Ibid. Mendelsohn observes that Białystok-based weavers "were not the only workers to disregard the advice and guidance of the organized movement;" ibid., 93.

${ }^{52}$ Ibid., 94, including note 1.

${ }^{53}$ Ibid., 94.

${ }^{54}$ Arlette Farge, Jacques Revel, The Vanishing Children of Paris: Rumor and Politics before the French Revolution, trans. Claudia Miéville (Cambridge, 1991), 52, 57. 


\section{The Republic of Krynki}

Before immersing ourselves in Weissenberg's $A$ Shtetl, let us assay the developments in a particular town amid the revolutionary events of 1905 as presented in the historical literature. Krynki, an industrialized shtetl halfway between Białystok and Grodno, was known for its tanneries and workers' movement, which was established as far back as the 1890s. The entire world became acquainted with this town in January 1905. Following the Bloody Sunday killings in St. Petersburg, Krynki's workers occupied local "government institutions," cut off the telegraph wires, and proclaimed a short-lived autonomous republic.

For the most part, the annals of the workers' movement in this shtetl are presented through the eyes of two rival parties - the Bund and the Polish Social Democrats (PSD, also known as SDKPiL). ${ }^{55}$ Both parties organized illegal meetings on the outskirts of town and distributed revolutionary prints. Krynki was already the scene of strikes in the 1890s. Yosl Cohen, a native son of this town who went on to become a communist poet in the United States, recalled the atmosphere during these years:

[T] he class-struggle was not a theory written down in agitation booklets. At a time when there was no industry in the neighboring towns, socialism was a kind of toy for intellectuals and enlightened. However, in Krynki, ideas of social revolution became the goal of almost all the youth. ${ }^{56}$

Socialist books and leaflets were widely disseminated in Krynki. By 1905, the shtetl's young workers were indeed quite familiar with these ideas. They turned to these works for validation of their revolutionary zeal, rather than political guidance that advocates "discipline and planning." More specifically, Cohen wrote:

They believed that the only thing that needed to be done was to disarm some policeman, to tear down the portrait of the emperor, and to declare the "rule of the proletariat" ... Those young people, who had already joined the Bund or anarchists, knew "for sure" that it depended exclusively on them whether the world would be established as a community of "freedom, equality, brotherhood, and justice." ${ }^{57}$

\footnotetext{
55 Jewish sources usually refer to the SDKPiL as the PSD (Polish Social Democrats).

56 Yosl Cohen, Vi nekhtn geshen (New York, 1953), 210.

57 Ibid.
} 
The tension between the aroused masses and class parties can be discerned between the lines of historical works concerning the events of January 1905. In his history of the Bund, Henry J. Tobias opens the account of the revolution in Krynki as follows: "[T] he Bund leaders formed a committee with the Polish Social Democrats, which decided to halt all work and to attack government offices." ${ }^{58}$ The Bund is presented as a political force that took the decision to launch the attack and subsequently led a demonstration that "captured the post office, cut off all communication with the outside world, and wrecked the police station and [destroyed] its records . . . leaving the town, as the Bundists expressed it, "clean." 59 A couple of pages later, though, Tobias admits that the Bund representatives in Krynki probably did not understand the request of the party's Central Committee as "instructions to initiate an all-out insurrection ... even though the demonstrators went further and seized the government buildings. $" 60$

Abram D. Kirzhnits also described the events of January 1905 from the standpoint of political parties. However, when examining specific details, his findings inadvertently prove the agency of the crowd:

Regarding the form and content of the January revolt, the whole field of the Jewish workers' movement can be divided into four scenarios: first, where the revolt had a mixed economic and political character; second, where for different reasons the Bund's directive could not be fully carried out; third, where they were generally carried out in full; and fourth, where proposals of the center were even surpassed. ${ }^{61}$

Obviously, Krynki falls under the fourth category. What, then, were the forces that pushed the revolt far beyond what the party representatives had called for? While Kirzhnits stresses that the uprising in this town was led by the Bund and SDKPiL,${ }^{62}$ the report of Grodno's governor-general, which he indeed cites, offers no information about political organizations. Instead,

${ }^{58}$ Henry J. Tobias, The Jewish Bund in Russia: From Its Origins to 1905 (Stanford, 1972), 297.

${ }^{59}$ Ibid. The report "the shtetl was clean and entirely in our hands" also surfaces in the account of Abe Lev, which is discussed below.

${ }^{60}$ Ibid., 299 (emphasis mine). For the statement of the Bund's Central Committee from January 1905, see Abram D. Kirzhnits, Moisei Rafes (eds.), Der yidisher arbeter. Khrestomatye tsu der geshikhte fun der yidisher arbeter, revolutsyonerer un sotsyalistisher bavegung in Rusland (Moscow, 1925), 2: 135-136.

${ }^{61}$ Abram D. Kirzhnits, Moisei Rafes (eds.), 1905. Evreyskoye rabocheye dvizheniye: obzor, materialy i dokumenty (Moscow-Leningrad, 1928), 78.

62 Ibid., 81. 
it describes a "general strike of workers of numerous leather-professions" and characterizes the revolutionaries simply as "a crowd." 63

Yosl Cohen, who titled the relevant chapter in his memoirs "Workers' Rule in Krynki," also implies that the political elements were unable to dictate the scale of the activities. While calling for a demonstration, "the leaders of the Bund did not plan to incite the workers' rebellion." All they wished to do was ratchet up the tanners" "revolutionary consciousness." ${ }^{64}$

The role of the crowd and its relation to the political parties is even more ambiguous in Naum A. Bukhbinder's Di geshikhte fun der yidisher arbeter-bavegung in Rusland [The History of Jewish Workers' Movement in Russia]. In the opening words of the chapter devoted to 1905, he asserted that ten years of organizational work on the part of the Bund among the Jewish hoi polloi had laid the groundwork for the "great success" of this "strike-wave [which] spread to all the cities and shetlekh." ${ }^{65}$ However, the conviction of Bukhbinder's top-down theory appears to waver in his depiction of the fallout from Bloody Sunday. He chronicles the events in specific places, such as Vilna, Minsk, and Grodno, as though the demonstrations in each town and city evolved in a singular, autonomous manner. Furthermore, he admits that the Bund leadership was hard-pressed to control the unexpected magnitude of these events. ${ }^{66}$ Bukhbinder's account of Krynki is of particular interest:

[A] mass-meeting of workers of all professions was organized in the local synagogue. In the end, the entire crowd (more than 2,000 people) fanned out along the streets of the town. The post-office functionaries, police, and town officials were dispersed. The police escaped from the town in fear. The town remained in the hands of the insurgent workers. The Bund organization formed the patrols to maintain order. ${ }^{67}$

The agency in this passage seems to have been ascribed to the "entire crowd" (gantzer oylem), whereas the party was essentially relegated to keeping the order once the revolutionary genie was out of the bottle.

63 Ibid., 82.

${ }^{64}$ Cohen, Vi nekhtn geshen, 227.

${ }^{65}$ Naum A. Bukhbinder, Di geshikhte fun der yidisher arbeter-bavegung in Rusland (Vilna, 1931), 326.

${ }^{66}$ Scott Ury also points to the Bund's inability to fully control the January strike in Warsaw. In his estimation, though, this state of affairs was destined to weaken the city's revolutionary movement. Ury, Barricades and Banners, 119-120.

${ }^{67}$ Bukhbinder, Di geshikhte fun der yidisher arbeter-bavegung, 330-331. 
Abe Lev, a tanner who was a member of the Krynki workers' movement, offered his own account of the insurgency:

[W] received an appeal from the Białystok committee of the Bund and also from the local branch of the Polish Social Democrats (SDKPiL) to join the open fight of the comrades in Petersburg. We set up a federative committee consisting of the leaders of our Bund organization and those of SDKPiL, and the committee created a general plan of action. We have decided to force a town-wide work stoppage, hold a demonstration, and attack all the regirungs-anshtaltn [government institutions]. For the sake of declaring the political strike, our organizations [i.e., the Bund and the Social Democrats] decided to hold a mass meeting in the beit midrash. There were more than 1,500 people, workers of various professions in Krynki, and they all came as one to the meeting, in response to our call. The bimah [central platform from which the Torah is read] was decorated with two red banners—of the Bund and the SDKPiL. After the meeting, the mass enthusiastically went out into the street. At the vanguard was the shlakht-grupe [fighting squad], revolvers in hand. The protesters descended upon the market square-the center of the shtetl. ${ }^{68}$

Lev stressed the discipline of the crowd. It arrived "as one" (vi eyn mensh) to the meeting that was convened by the parties. Thereafter, it embarked on an orderly yet spirited march aimed at wresting control of the town. This particular testimony leaves no doubt that the parties were in full control of the Revolution. According to the tanner, "our workers" seized government funds and handed them over to the "organization." That said, he also mentioned the presence of anarchists, who took money for themselves. ${ }^{69}$ Although Krynki soon became a major center of the anarchist movement, it stands to reason that Lev, who was a Bund activist, used this term to refer to those demonstrators who refused to heed the wishes of the party brass.

Many of the historians that researched the 1905 Revolution in Krynki drew heavily on Lev's account. A case in point is Sophia Dubnov-Erlich. The daughter of Simon Dubnov, the renowned historian, and wife of Henryk Erlich, one of the Polish Bund's interwar leaders, Dubnov-Erlich also wrote poetry. In her study on tanner and brush-maker unions, she repeated, almost verbatim, the above-cited passage. What is more, the historian-cum-poet introduced new elements that shed further light on this episode:

The leaders of the Bund and SDKPiL created a federative commission, which worked out a general plan of action. It was decided to force a town-wide work

${ }^{68}$ Kirzhnits, Rafes, Der yidisher arbeter, 2: 149.

69 Ibid., 150. 
stoppage, to hold a demonstration, and to attack the government institutions. For the sake of declaring the strike, the organization decided to hold a mass-meeting in the beit midrash. All the workers from Krynki came to the meeting. The bimah was decorated with two red banners- of the Bund and SDKPiL. The speakers talked about 9 January [i.e., Bloody Sunday], about the beginning of the revolution; but an anfirer [leader] of the demonstration urged: "Now is not the time for speeches." And the mass enthusiastically went out into the street. At the vanguard was a kampfgrupe [fighting squad], and the demonstrators headed to the market square. ${ }^{70}$

Notwithstanding Dubnov-Erlich's vague terminology (i.e., "it was decided"), the overall context suggests that the decision to attack "the government institutions" was made by the inter-party commission. The denouement of her narrative is the intervention of a somewhat mysterious anfirer (possibly an activist from the tanners' unions). This figure, who is absent from Lev's account, clearly interrupted the speeches of the parties' leaders. From this point onwards, the agency is in the hands of the excited mass, which becomes a crowd: "It was said that the demonstration was shot at, but the mass was enthusiastic and decided to put up a courageous resistance. Together with zeytike menshn [outsiders] it became an oylem [crowd] of several thousand people. The police hid away." 71

Peppering her narration with biblical allusions, organized labor is joined by an erev rav or "mixed multitude" (Exodus 12:37-38). The presence of these "outsiders" in Dubnov-Erlich's account is of utmost importance, for they transform molar subjectivities into a truly revolutionary multitude—oylem ("crowd" or "world"). Against this backdrop, the tension between the gantzer oylem and "the Bund organization" in Bukhbinder's above-cited narration speaks volumes.

Furthermore, Shmuel Agursky's introduction to an anthology that he edited, 1905 in Vaysrusland [1905 in Belarus], is most revealing. This work also hones in on Krynki, where "the manifestation achieved the highest step, the workers captured the whole town, and chased away all tchinovnikes [tsarist officials]."72 In the next paragraph, Agursky observes that the gemishter bafelkerung ("mixed multitude") of the land would soon be organized into distinct national political parties. Put differently, the masses underwent political overcoding. ${ }^{73}$

${ }^{70}$ Sophia Dubnov-Erlich, Garber-bund un bershter-bund (Warsaw, 1937), 77.

${ }^{71}$ Ibid., emphasis mine.

72 Shmuel Agursky, 1905 in Vaysrusland (Minsk, 1925), viii.

${ }^{73}$ Ibid., ix. In Agursky's account, "mixed population” refers to Jewish workers and nonJewish peasants. 


\section{Isaac Meir Weissenberg's A ShtetI}

As we have seen, it is the cracks and inconsistencies of historical studies on the January revolt in Krynki that expose the inadequacy of narrations revolving around molar political organizations. I have deliberately referred to works by authors who were apparently cognizant of the revolution's molecular dynamics. That said, these historians have only acknowledged the existence of the "mixed population," namely the oylem composed of workers and "outsiders," that operated alongside the Bund and SDKPiL. In an effort to understand the micropolitical anatomy of the events under review, we will read $A$ Shtetl as a text that exemplifies the "instantaneous apprehension" of a rebellious multitude. Weissenberg depicted a handful of entangled interplays or relations between the following: "archaic forms" of protest and modern ideologies; the crowd and political parties; and molecular process and molar organization within the revolutionary crowd itself. Thereafter, the focus will shift to the question of revolutionary violence, which novelist grasped in all its complexity.

Apprehending the dimensions of revolutionary events that transcend the realm of molar political overcoding does not, of course, mean that we will neglect the influence of political propaganda or the party activists. Nonetheless, external political elements will be viewed as secondary figures rather than as main protagonists, who interacted with local movements to kindle revolutionary outbursts. In his narration, Weissenberg indeed mentions these outside factors.

The novella begins on the Passover eve. Young men, who came home from Warsaw for the holiday, talk about strikes and demonstrations and introduce a new song to the community. Although Weissenberg does not mention the song by name and only provides its first two lines, the reader easily identifies the work as Di shvue [The Oath] — the Bundist anthem that was penned by S. An-sky in 1902. Yekl the carpenter, the leader of the town's discontented youth, decides "with a happy smile" that this song is "even better than the old ones," for it demonstrates that the revolutionary movement "is going forward more and more." " Once the visiting sons

${ }^{74}$ Isaac Meir Weissenberg, $A$ Shtetl, in $A$ Shtetl and Other Yiddish Novellas, 35. At certain points, I have modified Wisse's rendering. The Yiddish original is I. M. Weissenberg, Geklibene verk (Varshe, 1930), 1: 15. [Henceforth: Weissenberg, $A$ Shtetl; while citing these editions, I put two pages - the first referring to Wisse's English translation, the second to the 1930 edition of the Yiddish work. It also bears noting that Wisse rendered her work on the basis of the 1911 edition.] 
leave town, the remaining workers revert, much to Yekl's chagrin, to their old ditties about unrequited love. ${ }^{75}$ According to Ruth Wisse, these "sorrowing ballads of . . . love give way to rhythmic hymns of political allegiance." "76 However, this reading is off target. Weissenberg accentuates the perseverance of the "old ditties," which should be considered a form of popular self-expression and even resistance. ${ }^{77}$

The novelist also invokes another "ditty:"

What good is this life to you, brothers,

A life full of hunger and pain? ${ }^{78}$

The words that describe each of the exhibited songs appear to have been selected with care. Weissenberg refers to Di shvue as a lid ("song"). Conversely, this one begins as a lidl ("ditty") only to become a gezang ("chant" or "hymn"). As the workers take to the song, it is increasingly intoned in a "loud and mighty" fashion. Both the popular ditties and An-sky's new political anthem give voice to the workers' feelings, passions, sufferings, and hopes. The latter does not replace old songs, but is incorporated into the playlist. It is worth noting that Di shvue was preceded—as the Bund's anthem—by Di alte shvue [The Old Oath]. The latter was sung, for example, in Krynki during the town's strike of 1897. According to Józef Kozłowski, Di alte shvue is "replete with biblical motifs, naïve metaphors and phraseology, and grievances of the exploited." ${ }^{\prime 79}$ In his disquisition on Antonio Gramsci's works, the intellectual Ernesto de

${ }^{75}$ In describing these songs, Weissenberg used the word lidl. Conversely, he labelled Di shvue as a lid; cf. below.

${ }^{76}$ Wisse, "Introduction," 26.

${ }^{77}$ Portelli comments on the idea of synthesizing history with folklore and ethnology: " $[\mathrm{H}]$ istory of the working classes ought not to be limited to the history of the leadership of the major unions and parties, but should rather include all their organized and spontaneous forms of expression (including non-political and conservative ones)." Portelli, "Oral History in Italy," 393. Ernesto de Martino, an Italian anthropologist, deems such forms of expression to be means of "recovery and reintegration for critical moments of existence, with a marked preference for . . the theme of frustrated eros." Ernesto de Martino, The Land of Remorse: A Study of Southern Italian Tarantism, trans. Dorothy Louise Zinn (London, 2005), 245. It is worth noting that studies on Jewish folklore became an important part of early Jewish historiography in Eastern Europe.

${ }_{78}$ Weissenberg, $A$ Shtetl, 37/20-21.

79 Józef Kozłowski, Śpiewy proletariatu polskiego [Songs of Polish Proletariat] (Kraków, 1977), 93. Also see Tobias, The Jewish Bund in Russia, 44: "In 1896 the half-intellectuals created what is considered the first modern Jewish revolutionary hymn, 'The Oath.' The more famous Bund hymn, also titled 'The Oath' was composed in 1902 by Sh. An-sky." Four different versions of Di alte shvue are displayed in Shmuel Agursky (ed.), Di sotsyalistishe literatur oyf yiddish in 1875-1897 (Minsk, 1935), 2: 248-252. 
Martino coined the phrase "progressive folklore." Moreover, he argued that to succeed, revolutionary culture cannot be "a gift sent from above, but a real, concrete, molecular movement inside the popular world. Theoretical consciousness of the working class would risk becoming sectarian, immature consciousness, were it not able to recognize the value and function of the progressive folklore." ${ }^{\circ 0}$

The external factors in $A$ Shtetl are not limited to the holiday returnees. Weissenberg includes the mysterious figure of a "young stranger. ... An odd creature this was - frail and pallid, wearing a blue shirt belted with red sash, a collar pin at the throat, a soft black hat on his head and long black curls hanging loosely over his shoulders." ${ }^{\prime 1}$ Over the course of this novella, men of this sort come and go. Although these figures indeed help fan the flames of dissent, the uprising is not dependent on their efforts. The budding rebellion swirls to and fro, temporarily uniting people under its banner only to disperse various groups back into the daily grind:

[A]s soon as the shoemakers returned to their jobs, other workers went out on strike; they swarmed through the market place as the others had done, with their hands in their pockets, or huddled in redlekh [small clusters] ${ }^{82}$ whispering ceaselessly. Not for a moment that summer was the market place empty. One strike followed another; not a workshop or factory was spared. ${ }^{83}$

At the height of this unrest, the political parties turned up:

Not a week went by without visits from two or maybe three revolutionaries, members of the Jewish Labor Bund. But as soon as the Polish Socialist Party learned of the spreading influence of its chief rival, the Bund, they sent down a permanent organizer to do something about the situation. ${ }^{84}$

This competition led to a public debate between the parties, on the basis of which the insurgent workers were supposed to choose one of the two. In other words, the crowd's molecular flux was interrupted by its molar segmentation. More specifically, the oylem (crowd) turned into "a thick silent

${ }^{80}$ Ernesto de Martino, Stefania Cannarsa, "Due inediti su Gramsci: 'Postille a Gramsci' e 'Gramsci e il Folklore,"' La Ricerca Folklorica 25 (1992), 78.

${ }^{81}$ Weissenberg, $A$ Shtetl, 36/18-19. This portrait brings to mind the historical figure of one Johannes Holzmann (Senna Hoy). Stirring up the anarchist movement during the Revolution of 1905, he was active in dozens of cities and towns, including Warsaw, Białystok, and Łódź.

${ }^{82}$ Wisse translates redlekh with the less literal "clusters." In any event the word seems to capture the dynamics of the various worker groups.

${ }_{83}$ Weissenberg, A Shtetl, 40/26.

${ }^{84}$ Ibid., 47/38. 
mass that blackened the field around [eyn gedikhte makhne, eyn shvartze shtil-shveygndike kupe]." ${ }^{85}$ It then broke off into party clusters, if only for the time being. As we will see, the two words-oylem and makhne - are chosen very carefully. At the pivotal march, the crowd (oylem) regained its brio: the faces of the participants were "aglow with collective joy. A song started up, growing louder and bolder till it flooded the entire street." ${ }^{86}$ However, even at the height of revolutionary zeal, molar organizations appeal to the crowd. Weissenberg describes with playful irony how the banners of the PPS and the Bund were prepared: "the young men wanted a banner of their own. The PPS man, when he became aware of it, was afraid that Yekl might take the initiative, just as Yekl was afraid that the PPS man might do the same. Overnight in the teashop two flags were readied." ${ }^{87}$ Also here the author meaningfully chose his words. Though Wisse rendered farkhafn "to take initiative," its literal meaning is to seize, capture, usurp, or appropriate.

Weissenberg's sarcasm reaches its climax when the party representatives ascend the podium. The PPS speaker "shifted his tone, like a comedian, and began to call to his comrades in a higher, sharper voice: 'Bratshe, tovarishtshe [Brothers, comrades]!' he exclaimed, his mouth chopping the words like lettuce for a salad." 88 These exhortations aside, when rumors that soldiers were approaching the town began to spread, "the PPS man, according to one of the local coachmen, had made off by train in the middle of night." ${ }^{99}$

David Roskies has aptly dubbed $A$ Shtetl the first "study of violence through radical politics" in Yiddish and Hebrew fiction. ${ }^{90}$ Weissenberg indeed offered a nuanced, multilayered analysis of violence, which both held the shtetl community together and tore it apart. Mikhail Krutikov duly urges scholars to go beyond an analysis of this novella that merely draws a contrast "between naturalistic and neoromantic trends in the representation of the shtetl." ${ }^{\prime 11}$ Nevertheless, he also has eschewed a fullfledged non-reductive reading. In my estimation, Krutikov's claim that

${ }^{85}$ Ibid., 47/39. As discussed below, Weissenberg subsequently uses these same words to describe the latent violence of the peasants' procession.

${ }^{86}$ Ibid., $57 / 57$.

${ }^{87}$ Ibid., $55 / 55$.

${ }^{88}$ Ibid., $58 / 60$.

${ }^{89}$ Ibid., 59/62.

${ }^{90}$ David G. Roskies, Against the Apocalypse: Responses to Catastrophe in Modern Jewish Culture (Syracuse, 1999), 113.

${ }_{91}$ Mikhail Krutikov, Yiddish Fiction and the Crisis of Modernity, 1905-1914 (Stanford, 2001), 87. 
$A$ Shtetl "presents the negative side of the revolution, the self-destructive violence that threatens the very existence of the traditional Jewish communal organism" $" 92$ is overly simplistic. Even if he accurately observes that Weissenberg did not "value this organism very much," his conclusion whereby the novelist sufficed with demonstrating that "the new order that the revolutionaries try to establish can be only worse" ${ }^{93}$ is too precipitous. Even less accurate is Krutikov's suggestion that the work depicts revolutionary masses as "corrupt and dull men incapable of grasping new concepts." ${ }^{94}$ In fact, Weissenberg astutely reflects on violence as both molar and molecular phenomenon.

The very first scene of $A$ Shtetl grapples with the problem of violence. Set in the town's beit midrash (study hall), the opening image of the "Jewish community united under God" is immediately sundered, as Roskies puts it, into "identifiable clusters of shopkeepers, tailors, shoemakers, butchers, teachers." ${ }^{95}$ Soon after, this segmented molar organization is confronted by a "knot of young men" (kupkele yungvarg), ${ }^{96}$ or what Deleuze and Guattari refer to as a "pack," ${ }^{\prime 97}$ who rail against the monopoly on flour for the Passover matzot. This protest is not merely the latest round in an age-old struggle with the community establishment, for Weissenberg did not confine himself to molar segmentation along class lines. ${ }^{98}$ Instead, he painted a much more complex picture: the town's social order was predicated on the segmentary organization of traditional artisans' guilds (khevres)—organizations that simultaneously bound people of particular crafts together and situated them as distinct units in the hierarchical structure. Eventually, Weissenberg reached the molecular level in a scene depicting a violent assault of the butchers' guild against the above-mentioned youth: "The place suddenly became a jumble of blazing faces, a riot of entangled arms and heads. The shouts blended into a yam koyles [sea of voices]." ${ }^{99}$ While segmented organisms can only be preserved with force, this violence upset the communal hierarchy and invigorated its molecular components.

${ }^{92}$ Ibid.

${ }^{93}$ Ibid.

${ }^{94}$ Ibid., 88.

${ }_{95}$ Roskies, Against the Apocalypse, 112.

${ }_{96}$ Weissenberg, $A$ Shtetl, 30/6.

${ }^{97}$ Deleuze, Guattari, $A$ Thousand Plateaus, 33.

${ }^{98}$ See ibid., 213.

${ }^{99}$ In rendering yam koyles a "roar," Wisse strays from a literal translation. Weissenberg, $A$ Shtetl, 31/8. 
The butchers certainly won this encounter, but the youth were undaunted: "On a seasonable Saturday morning, Itchele decided that the time had finally come to get even with the butchers for their bloody triumph before the holiday." 100 Once more, a brawl ensues: "There was a wild tangle of arms and heads.... The mass of heads locked together by teeth and clutching fingers was like a single clumsy massive beast with a thousand moving limbs, heaving and stumbling from one side of the room to the other." 101 In the end, the youth prevail, "their bruised faces suffused with joy." Summing up the fracas, Yekl the carpenter opines that "sometimes a bit of terror could do no harm." 102 According to Jonathan Frankel, this scuffle constitutes the decisive moment in this story. What began as "a harmless protest against the unfair price of matzot, moves on step by step toward a civil war fought out, albeit in miniature, among the Jews of the shtetl." 103

Weissenberg was apparently experimenting with the same idea that Frantz Fanon would articulate a half century later: "At the individual level, violence is a cleansing force. It rids the colonized of their inferiority complex, of their passive and despairing attitude. It emboldens them, and restores their self-confidence." ${ }^{104}$ Likewise, $A$ Shtetl underscores the joy that accompanies revolutionary violence. One finds the same emotion in a poem, 1905, by Yosl Cohen, who witnessed the insurrection in Krynki as an eight-year-old boy:

Such dancing joy

you poured into our spirits!

Not by miracle

did this brightness reach to all horizons:

from our own exploded fury,

with a roar of ripped limbs,

and from our own blood

on fertile fields, faith blossomed.

And all along with myself I brought to the earth a ripened fury bred by the tanneries of Krynki. ${ }^{105}$

${ }^{100}$ Ibid., $45 / 34$.

101 Ibid., 45-46/35-36.

${ }^{102}$ The original Yiddish reads thus: "es shadt nisht amol 'teror' ojkh.” Ibid., 46/37.

I have modified Wisse's rendering of this passage.

${ }^{103}$ Frankel, Crisis, Revolution, and Russian Jews, 94.

${ }^{104}$ Frantz Fanon, The Wretched of the Earth, trans. Richard Philcox (New York, 2004), 51.

105 Yosl Cohen, "1905," in Aaron Kramer (ed. and trans.), A Century of Yiddish Poetry (New York-London, 1989), 275-276. 
By virtue of this joy, the revolutionary moment is a creative force, not a destructive one. In 1907, Gustav Landauer, a German-Jewish anarchist thinker, wrote that "[T]he joy of revolution is not only a reaction against former oppression. It lies in the euphoria that comes with rich, intense, eventful life. What is essential for this joy is that humans no longer feel lonely, that they experience unity, connectedness, and collective strength." 106 Weissenberg understood this elation as the hope for a new form of solidarity- "the One of multitude." That said, he also realized the dangers that it posed. Roskies suggests that $A$ Shtetl's "strikers were reduced to faceless mobs propelled by the cycles of growing violence." 107 In my estimation, though, the novelist grasped the ambiguity of violence-the fact that such force is both liberating and detrimental at one and the same time. It is no accident that he referred to the young men under Itchele's command as a makhne (group) - this word is used in the novella every time violence stamped out the multitude and transformed it into a body that is susceptible to molar overcoding. In parallel, the youths' attack against the butchers dismantled the town's compartmentalized organization and spawned "the One of multitude." Deleuze and Guattari note that "the State exercises power over the segments it sustains or permits to survive." 108 Accordingly, the shtetl revolution was directed at both the officials-the apparatus of the state-and the rigid division of society into khevres. As Landauer puts it, "revolution ignites a general fire among people and transcends borders (which are never stable)."109

This sort of turmoil can engender a new kind of non-molar unity that preserves the revolutionary movement's molecular dynamics. When the insurgent youth in Weissenberg's story began organizing secret nocturnal meetings "behind the new cemetery grounds ... the starshi-strazhnik [police chief] . . learnt about a new word—akhdes." ${ }^{110}$ However, this unity was

${ }^{106}$ Gustav Landauer, Revolution and Other Writings: A Political Reader, trans. Gabriel Kuhn (Oakland, 2010 [1907]), 171.

${ }_{107}$ Roskies, Against the Apocalypse, 118.

108 Deleuze, Guattari, $A$ Thousand Plateaus, 210.

${ }^{109}$ Landauer, Revolution and Other Writings, 115.

${ }_{110}$ Weissenberg, $A$ Shtetl, (38)/22-23. This passage is omitted in Wisse's translation. The relation between Weissenberg's novella and the actual events that transpired in Żelechów during the 1905 Revolution is the subject of debate. However, as evidenced by the testimony in the remembrance book of the Żelechów community, a sense of akhdes prevailed in this town as early as 1903: "Akhdes became influential among the youth, bokhurim [young lads] and girls, even in Hasidic circles." Wolf Yassni (ed.), Izkor bukh fun der Zhelekhover yidisher kehile [The Żelechów Memorial Book] (Chicago, 1953), 72. 
immediately threatened by the prospects that these same revolutionaries would establish a molar organization.

Weissenberg discerned how akhdes turns into organizatsye, ${ }^{111}$ how it reproduces old forms and endeavors to revive the mythical ones: ${ }^{12}$

Yekl gave everyone a sympathetic hearing and listened to all complaints. The shtetl grew to love him. Sometimes he was called Reb Yekl Dayan, as though he were now the official rabbinic authority. ... He even won the approbation of the Police Chief who called him "The Jewish Ruler" ... He spent a few hours of each day ... straightening out all the "legal problems" of the town and the surrounding district. It was all done in the name of the organization. ${ }^{113}$

These efforts transformed the revolutionary leader into a rabbi, a king, or a judge. ${ }^{114}$

Once an organization takes form, though, the violence reappears as a purely destructive force. In his commentary on $A$ Shtetl, Roskies observes that an "abuse of the movement's powers" 115 resulted in a fatality. As a result, Itchele, one of the local activists, upbraided Yekl: "[I]f you couldn't control it [i.e., the insurgency], you shouldn't have undertaken it." also Weissenberg's narration is appreciably more subtle than Krutikov's interpretation thereof. The latter erroneously defines the revolutionary body as a khevre-“a group, equivalent to organizatsye." Moreover, he claims that "Weissenberg shows that Yekl and his comrades are above all interested in power, which they need in order to take revenge on their

${ }^{111}$ See Weissenberg, $A$ Shtetl, 51/46-47. The reason I am using Yiddish terms herein, instead of their English equivalents, is that, as we will see, the differences between khevre, akhdes, and organizatsye are essential to my reading of this novella. These nuances are overlooked in the existing translations and commentaries.

${ }^{112}$ Ferdinand Tönnies referred to this mythical community as Gemeinschaft; see Ferdinand Tönnies, Community and Association (Gemeinschaft und Gesellschaft), trans. Charles P. Loomis (London, 1955).

113 Weissenberg, $A$ Shtetl, 50-51/44, 46.

${ }^{114}$ In Yassni's edition, one Hershl Toker is described in a strikingly similar fashion. It thus stands to reason that he served as a model for Yekl in Weissenberg's novella. See Izkor bukh, 73. Interestingly enough, this same process characterizes the great Polish workers' strike of 1892 in Łódź. Adam Próchnik, the influential Polish socialist, observed that "the most important issue workers were preoccupied with was the need for leadership.... In the naïve thinking of the people it took the form of [the] election of [one of the insurgent tailors as] the 'Polish king'." Adam Próchnik, "Bunt łódzki w roku 1892. Studium historyczne" [Revolt in Łódź in 1892. A Historical Study], in id., Studia i szkice 1864-1918 [Studies and Essays 1864-1918] (Warsaw, 1962), 419.

115 Roskies, Against the Apocalypse, 113.

${ }^{116}$ Weissenberg, $A$ Shtetl, 52/49. The Żelechów Memorial Book mentions a fighting squad (boyuvke) that was organized by the akhdes; Izkor bukh, 73 . 
enemies." ${ }^{117}$ At any rate, the transformation of the molecular revolutionary mass (akhdes) into a molar organizatsye induced the town's prosperous inhabitants to form their own association (khevre) for the sake of countering this development. ${ }^{118}$ The "One of the multitude" is lost, superseded by molar class divisions. This turn of events indeed sets the stage for the novella's violent denouement.

The political parties also engender a violence-spawning molar organization. As soon as "the shtetl became known throughout the surrounding region for its powerful movement," representatives of the Bund and PPS turned up ${ }^{119}$ and ultimately held a debate. This event should have resulted in the populace's molar segmentation (and, as we have seen, the crowd's transformation into a makhne). The scene reaches its climax when one of the activists "drew his pistol and pulled the trigger! ... That was the first Jewish shot ever fired in our shtetl." ${ }^{120}$

Yet another external factor in this novella is the potentially violent non-Jewish populace in the vicinity. Weissenberg describes this group as a makhne, which Wisse has decided to translate as "multitude:" "[B]eyond the shtetl, lay such a vast makhne, and here everything was so small, so puny ... that if the thousands out there suddenly decided to have a bit of fun-just a simple bit of peasant fun-... nothing would remain of the shtetl but an empty plot of land." ${ }^{21}$ These peasants take to the streets en masse during the Sunday procession-a silent and "submissive multitude of thousands" (a toyzntike makhne, a shveygndike un untertenike). ${ }^{122}$ Acquiescent as it may be, this united throng - the "One of the people"harbors a latent power that can instigate a pogrom at any moment. In my estimation, Weissenberg's makhne is diametrically opposed to Virno's conception of "multitude." It also bears noting that the novelist referred to the procession as the narod-folk. This usage seems to correspond with Virno's "people," not his “multitude." 123

The final outside player in the novella is the state, which dispatches troops to restore order. Roskies points out:

117 Krutikov, Yiddish Fiction, 89.

118 Weissenberg, A Shtetl, 61/66.

119 Ibid., 47/38. In this context, Wisse translates bavegung as "organization."

${ }^{120}$ Ibid., $48 / 41$.

121 Ibid., 55/55.

122 Ibid., 53/51.

123 Virno defines "people" and "multitude" as "two polarities;" see Virno, A Grammar of the Multitude, $21 \mathrm{ff}$. 
Whatever choices made and whatever bloody victories won within the shtetl are overwhelmed by the larger forces that descend upon it from without ... By choosing to depict "the revolution in a glass of water," he [i.e., Weissenberg] lets two forces of destruction play themselves out: the one that disassembles the community by pitting young against old, workers against bosses, and the other that regards all classes and age groups within that community as rabble. ${ }^{124}$

From my perspective, this contention is a bit too rash. The "[force] that disassembles the community" is in fact the violence that keeps it intact; and such power is vested in every molar organization. In A Shtetl, this violence is constantly unleashed to prevent the "rabble"-either the entire shtetl or the agitated youth-from becoming a multitude.

Confronted with the external violence of the narod and state, Weissenberg's shtetl was destined to lose the remnants of its multitude. Deleuze and Guattari posit that the novella genre enables writers to circumvent "an impasse of the line of escape." What is more, a work of this sort should end when it "erects this impasse." Put differently, the genre "shows a way out, traces a line of escape, but is incapable of following it or making its own." 125 This is exactly what one finds in $A$ Shtetl. "Carefully balanced as to structure," Roskies notes, "the novella finishes as it began, in the house of study." ${ }^{26}$ The revolutionaries seize control of the place and interrupt a service that was called in order to pray for deliverance from this crisis: "'What good are psalms?' Yekl shouted ... 'This is no time for psalms. ... This is the time, not for psalms, but for arms!"”27 The rabbi's protest—“There are no arms ... only psalms!"-is brutally silenced: "'You're just a thief!' Yekl hollered him down, waving a finger in front of his face. 'Your scale is false. You put your foot on it whenever you're weighing anything." 128 Soon after, one of the rebels settles the debate between the proponents of violence and prayer by flashing a gun. Fearing for their lives, "[T] he congregation threw open the windows and began to leap out. Within a minute the study house was empty. There remained only the rabbi, who sat in the corner with his face to the wall, crying like a small child." The final triumph of violence is manifested by the arrival of the tsar's soldiers: "[W]hat if the street should die, just so, behind its locked shutters, as they were passing through?" 129

\footnotetext{
${ }^{124}$ Roskies, Against the Apocalypse, 114-115; emphasis in the original.

125 Deleuze, Guattari, Kafka, 36-37.

126 Roskies, Against the Apocalypse, 113.

${ }^{127}$ Weissenberg, $A$ Shtetl, 76/97-98.

${ }^{128}$ Ibid., 76/98.

${ }^{129}$ Ibid., $78 / 103$.
} 


\section{Conclusion}

To fully appreciate Weissenberg's molecular narration, we are best advised to contrast $A$ Shtetl with the "molar" (Bundist) narration in An-sky's In shtrom. Also published in 1907, the latter has the subtitle "A Tale of the Jewish Revolutionary Movement in Russia." ${ }^{130}$ An-sky's story also culminates with the revolutionaries taking over the local synagogue:

$[D]$ i alte shul [the Old Synagogue] . . regarded as the oldest building in N. [i.e., the town] ... has survived all the storms and disasters.... Around it, entire streets and quarters of the town have burnt down; generations of houses have decayed, crumbling away; but the synagogue stands, as though untouched by time or events. ${ }^{131}$

The revolutionaries, who also disturb a prayer service, are "self-confident ... without reverence for the house of prayer." Be that as it may, the revolutionaries and congregants eventually restore the bonds of unity: "The Jewish proletariat is fighting for its class interests," An-sky's revolutionary speaker exclaims, "but at the same time it fights for the freedom and life of the Jewish people." The aim of the "organized Jewish proletariat with weapons in hand" is to "defend Jewish homes from destruction, old men and children from slaughter." 132 What follows is a reconciliation between the two worlds. The labor activists step down from "the raised platform [and] only the old man who is holding the Torah scrolls tightly to his chest [remains] while, below, the young workers in a solid knot encircle the dais." 133

As we have seen, the link between Weissenberg's $A$ Shtetl and the actual events that occurred in his hometown of Żelechów is convoluted. Needless to say, the novella should not be interpreted as a representation of specific events or people. On the other hand, though, Weissenberg may have had real subjects very well in mind while penning this literary study of insurgent crowds. Although the seizure or re-appropriation of the beit midrash or synagogue is a well-documented revolutionary gesture in the Pale of Settlement, a comparison of the final scene of $A$ Shtetl with the account in the Żelechów Memorial Book is insightful. In the latter, the dynamics of the temple's occupation substantially differ from Weissenberg's image. Moreover, they closely correspond to An-sky's narration.

\footnotetext{
${ }^{130}$ See Frankel, Crisis, Revolution, and Russian Jews, 72-97.

${ }_{131}$ Quoted in ibid., 78.

${ }^{132}$ Ibid., 79-80.

133 Ibid., 80.
} 
The relevant chapter of the remembrance book is titled In shuts kegn pogromen [Defending against Pogroms]. Upon entering the synagogue, the revolutionaries declare: "With psalms one cannot fight the pogroms." An old man counters that he would choose kidush hashem (martyrdom, literally "sanctification of the Name") over heeding the call to arms. In response, one of the "occupiers" attempts to clear the air: "[W]e do not, God forbid, want to interrupt your psalm-singing. We just want to say a few words and later you will be able to sing the psalms." 134 Invoking appropriate verses from the Bible,${ }^{135}$ he argues that the revolutionaries only want to defend Jews against violence of pogroms. Eventually, the speaker wins the audience over. Although the revolutionaries do not believe in God, he persuades the devotees that his men are ready, in fulfillment of the Torah, to "sacrifice their lives" (moyser-nefesh, not kidush hashem) in order to save a Jewish life (nefesh). ${ }^{136}$

Weissenberg's firm rejection of such a conclusion speaks volumes. Pessimistic as he was when appraising the prospects of the molecular revolutionary multitude, the novelist refrained from completely writing it off. Even though Weissenberg knew that a multitude stands little chance of repulsing the violence of any molar organization, he remained faithful to the fleeting oylem that emerged in the very moment of revolt.

Piotr Laskowski

University of Warsaw ptrlaskowski@gmail.com

134 Izkor bukh, 74.

135 "He began with a quotation from Isaiah, which allowed him to appease the Jews. His speech, in which Torah quotations were intertwined, silenced them." Ibid., 75.

136 Ibid. 